\title{
NOTES ON RED CROSS NURSING
}

ManY nurses scem to fecl it a great responsibility to enroll for Red Cross service, for the reason that they are expected to answer emergency calls at short notiee. It will be seen under the information for enrollment of nurses in New York State (paragraph 2) that nurses unable to respond to the first call because of a professional engingement must signify their willingness to respond to a later call at a definite date. Thlis might possibly have been worded with even more elasticity hecause, of course, the Red Cross would never demand that a woman should leave a responsibility which required her personal attention even thongh the emergency were great, but it is of the utnost importance that the eommittee should] have a large list of nurses to call upon, so that in an emergency there would always be some that eould respond to the first call.

The New York committec has also decided to enroll dictitians for hospital service. Miss Corbett, the dietitian of the Department of Charities in Ncw York City, was suggested for membership on the Nurses' Committec, in order that proper rules night be compilerd for the enrollment of dietitians.

It may be of interest to know that the California Branch now has one hundred and eighty-eight nurses enrolled; the District of Columbia has thirty-seven uurses enrolled; and the New Ynok State Branch now has twenty-one nurses enrolled, and one dietitian; and has eight or more applications which liave not yet been considered.

In order to arousc grenter interest in led Cross nursing it has been suggested that the subject should be introduced into the training schools of New York State, that the pupils shall be properly instructed in the history of the Red Cross movement, its devclopment in the different countries of the world, and the important place that nurses are to occupy if the Socicty is to attain to its full extent of usefulness.

No better subject is before the alumnæ associations for winter study than that of the Red Cross. Lcetures ean be arranged for or printed matter secured by sending to the different state headquarters or to the office of the National Red Cross in Washington, District of Columbia.

We give below rules for eurollment in New York, also resolutions adopted by the Executive Committee of the American National Red Cross, October 18, 190\%, all of which is instructive and suggestive for alumnæ programs.

Enrollment eosts nothing and it places the voluntecr in the honor 
class of nurses. We should have five thousand Red Cross nurses in the United States before the end of the eoming year. Do it now.

\section{ENROLLMENT OF NURSES}

AuThoRITY.-The enrollment of nurses in the New York State Branch is under the joint authority of the State Nurses' Committee and the subdivisions, subjeet to the general regulations of the national organization.

Service and Remuneration.-- Eurolled nurses are called upon for services in the order of their enrollment. Nurses unalle to respond to the first eall, because of a professional engagement, must signify their willingness to respond to a later eall at a definite date. They may be either volunter or paid. 'The remuneration for paid service is the same as in the United States Ariny-forty dollars $(\$ 40.00)$ a month in the United States; fifty dollars $(\$ 50.00)$ in foreign eountries, together with transportation and maintenanee.

No FEE.- There is no fee for the enrollment of nurses.

Membensitip Optionat.-The Red Cross murse may also beeome a member of the American National Red Cross by joining the local branch, for which dues are one dollar $(\$ 1.00)$ a year. The membership is, howaver, entirely optional with the nurse.

Application.-Nurses desiring to be enrolled for lied Cross service should apply by letter to the offiec of the "New York State Branch of the American National lied Cross, No. 500 Fifth Avenue, New York City," or to the secretary of their loeal subdivision, asking for a eopy of the "Rules for the Enrollment of Nurses" and for an "Applieation IBlank."

Rulis for Enroldanent.-These rules require (1) State registration; (2) references; (3) minimum age limit of twenty-five years; (4) physician's eertifieate of health; and (5) approval by a member of the Nurses' Committee after personal interview. If these requirements can be fulfilled, the nurse should fill ont the application blank fully and explicitly and return with the papers required by the rules to the State offiee.

If the other requirements are satisfactory, the nurse will reeeive notice to call upon a member of the Nurses' Coinmittee.

Contract and Certificate.-Having received this final approval. the nurse will be given a nurse's agreement to sign and a eertificate as a Red Cross nurse. Enrollment as a Red Cross nurse holds good, subject to the renewal of physieian's certifieate of health every two years, until the nurse filcs notice in writing of withdrawal from enrollment. 
'TiLe Nurse's BaDge.-At the time of enrollment, every Red Cross nur'se is given a Red Cross nurse's badge, the number and name engraved on the back. Under the Act of Congress incorporating the Red Cross, this badge cannot be worn by any one clse. The badge is owned by the Ancrican National Red Cross, and at no time becomes the property of the nurse. It should be worn on the front left hand side of the collar. In case of witlidrawal from enrollment, the Red Cross nurse's badge and certificate must be returned.

Tine Brassard.- The Red Cross brassard consists of a red cross on a white arm band, and is worn on the left arm. The brassard ean be worn only in time of official active scrvice in the field. Brassards are furnished and owned by the American National Red Cross.

The Exrollanent of Administrative Nurses.-Superintendents of experience may enroll for administrative work under the same general rules as those which govern the nurses. A special blank will be furnished for such enrollment.

APPLICATION FOR GENERAI, NIRSING SERVICE

1. Name in full:

2. Address:

3. Telephone number:

4. Age:

5. School:

6. Date of graduation:

7. Are you registered and in what state?

8. Do you cnroll for paid or volunteer nursing services in the Rerl Cross?

9. What experience have you had since graduation, in private, institutional or district nursing; in sanitary inspeetion, in epidemies. and in investigation for giving discriminate relicf?

10. References.

RESOLUTIONS ADOPTED BY TIE EXECUTIVE COMMITTEE OF THE AMERICAN NATIONAI, RED Cross, oCTOBER 18, 1907.

Whereas, By international agreement in the Treaty of Geneva, 1864, and the reviser Treaty of Geneva, 1906, "the emblen of the Red Cross on a white ground and the words Red Cross or Geneva Cross" were adopted to designate the personnel protected by this Convention, and

Wirereas, The Treaty further provides (Article 23) that "the cmblem of the Red Cross on a white ground and the words Red Cross or 
Geneva Cross ean only be used whether in time of peace or war, to protect or designate sanitary formations and establishments, the personnel and material protected by this Convention," and

Winereas, The Ameriean National Red Cross eomes under the regulations of this 'Treaty according to Article 10, "volunteer aid societies, duly recognized and authorized by their respective Governments," such recognition and authority having been conferred upon the American National Red Cross in the Charter granted by Congress, January 5, 1905, Sec. 2, "The corporation hereby ereated is designated as the organization which is autlorized to aet in matters of relief under said 'Treaty," and, furthermore,

Wireneas, In the Revised Treaty of Geneva, 1906, in Artiele 27, it is provided that "the signatory powers whose legislation should not now be adequate. engage to take or recommend to their legislatures suel measures as may be neessary to prevent the use by private persons or by societies other than those upon which this Convention confers the right thereto of the emblem or name of the Red Cross or Geneva Cross,"

Be tr Resolven, That the Executive Committee of the Ameriean National Red Cross requests that all hospitals, henlth departments and like institutions kindly desist from the use of the Red Cross ereated for the special purpose mentioned above, and suggests that for it should be substituted some other insignia, such as a green St. Andrew's Cross on a white ground, to be ninued the "Iospital Cross," and used to designate all hospitals (save sueh as are under the Medieal Departments of the Army and Nary and the autlonized volunteer aid society of the Government), all health departments and like institutions, and, further,

Be it Resolved, That the Executive Committee of the Ameriean National Red Cross likewise requests that all individuals or business firms and eorporations who employ the Geneva Red Cross for business purposes, kindly desist from such use, gradually withdrawing its employment and substituting some other distinguishing mark.

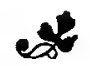

"With angels therefore sing again,

To God on high all glory be;

For peace on earth bestoweth $\mathrm{He}$

And showeth favor unto men." 